Nat. Hazards Earth Syst. Sci., 18, 1-13, 2018

https://doi.org/10.5194/nhess-18-1-2018

(C) Author(s) 2018. This work is distributed under

the Creative Commons Attribution 3.0 License.

\title{
Exploiting LSPIV to assess debris-flow velocities in the field
}

\author{
Joshua I. Theule ${ }^{1,3}$, Stefano Crema ${ }^{2}$, Lorenzo Marchi ${ }^{2}$, Marco Cavalli ${ }^{2}$, and Francesco Comiti ${ }^{1}$ \\ ${ }^{1}$ Faculty of Science and Technology, Free University of Bozen-Bolzano, Bozen-Bolzano, 39100, Italy \\ ${ }^{2}$ Research Institute for Geo-hydrological Protection, National Research Council of Italy, Padova, 35127, Italy \\ ${ }^{3}$ TerrAlp Consulting, 100 chemin du grand pré, 38410 St Martin d'Uriage, France
}

Correspondence: Joshua I. Theule (joshua.theule@ terralpconsulting.com)

Received: 29 May 2017 - Discussion started: 28 June 2017

Revised: 25 October 2017 - Accepted: 9 November 2017 - Published: 3 January 2018

\begin{abstract}
The assessment of flow velocity has a central role in quantitative analysis of debris flows, both for the characterization of the phenomenology of these processes and for the assessment of related hazards. Large-scale particle image velocimetry (LSPIV) can contribute to the assessment of surface velocity of debris flows, provided that the specific features of these processes (e.g. fast stage variations and particles up to boulder size on the flow surface) are taken into account. Three debris-flow events, each of them consisting of several surges featuring different sediment concentrations, flow stages, and velocities, have been analysed at the inlet of a sediment trap in a stream in the eastern Italian Alps (Gadria Creek). Free software has been employed for preliminary treatment (orthorectification and format conversion) of video-recorded images as well as for LSPIV application. Results show that LSPIV velocities are consistent with manual measurements of the orthorectified imagery and with front velocity measured from the hydrographs in a channel recorded approximately $70 \mathrm{~m}$ upstream of the sediment trap. Horizontal turbulence, computed as the standard deviation of the flow directions at a given cross section for a given surge, proved to be correlated with surface velocity and with visually estimated sediment concentration. The study demonstrates the effectiveness of LSPIV in the assessment of surface velocity of debris flows and permit the most crucial aspects to be identified in order to improve the accuracy of debris-flow velocity measurements.
\end{abstract}

\section{Introduction}

Debris flows are rapid flows of saturated non-plastic debris in a steep channel (Hungr et al., 2001). They consist of poorly sorted sediments mixed with water and organic debris with sediment concentrations higher than $50 \%$ by volume or $70 \%$ by mass (Costa, 1984; Phillips and Davies, 1991) and can travel over long distances at relatively high velocities (generally between 2 and $20 \mathrm{~m} \mathrm{~s}^{-1}$; Iverson, 1997; Rickenmann, 1999). Debris flows are relatively infrequent and complex events, which makes it difficult to characterize their dynamic flow heights, velocities, discharge, and flow resistance of the material, among other aspects.

Debris-flow velocities and discharge are typically backcalculated from surveyed channel bends with superelevated flow heights using the forced vortex equation (e.g. Hungr et al., 1984; Chen, 1987; Prochaska et al., 2008; Scheidl et al., 2014). The measured parameters (flow heights, velocity, and slope) from post-event surveys for this equation can also be used to estimate flow resistance coefficients to understand the viscosity and sediment concentrations of the debris flows (e.g. Rickenmann, 1999). However, sediment concentrations are known to significantly increase and decrease during the propagation of the flow (e.g. Pierson and Scott, 1985; Rickenmann et al., 2003) and the velocity profile of the surges can also vary, thus limiting the reliability of post-event field methods.

Debris-flow monitoring projects are growing thanks to the increasing feasibility and capability of observing several parameters of this complex process (e.g. Marchi et al., 2002; Coe et al., 2008; Arattano et al., 2012; Navratil et al., 2013; Comiti et al., 2014). Typical monitoring stations consist of geophones, ultrasonic sensors (or radar), and video cameras 
which satisfy the basic measurements of velocity, height, discharge, and visual validation. Some catchments also present multiple stations distributed throughout the debris-flow channel and some located in headwater channels (Berti et al., 2000; Marchi et al., 2002; Hürlimann et al., 2003; McCoy et al., 2010; Arattano et al., 2012; Navratil et al., 2013; Comiti et al., 2014).

Video acquisitions originally started as a validation of the instrument recordings and visual interpretation, but as cameras, power, and storage capacities improve, further analysis can be made. Manual tracking of particles with field measurements can measure velocities accurately when compared to stage sensors (e.g. Arattano and Grattoni, 2000; Marchi et al., 2002). The video imagery of debris flow can also be used to interpret the turbulence, sediment mixture, sediment concentration, presence of rigid plugs, and laminar flows (e.g. Marchi et al., 2002). Horizontal velocity distributions from video imagery have shown variations of flow resistance between events and within the same surge (Genevois et al., 2001). Rheological parameters are known to significantly vary within the same surge, but they are very difficult to quantify in the field.

Large-scale particle image velocimetry (LSPIV) is another video imagery technique often used in rivers to measure two dimensional velocities from high-resolution images at high frame rates (e.g. Fujita et al., 1998; Hauet et al., 2008; Le Coz et al., 2010; Muste et al., 2014). Cross-correlations are made between time-step imagery within a given search window. This is typically applied in steady flows by tracking bubbles, ice, debris, and artificial seeding. Discharge rates can then be estimated because of the stable cross sections during the flow. LSPIV and series of elevation models were also compared during bedload transport flume experiments to quantify discharge and deposition as well as Froude and Shield's numbers.

These types of analysis are difficult for debris flows because the different surges can vary in height and significantly modify the channel bed. The LSPIV method was tested on a pulsing flash flood in a stable reach from a GoPro video recording that was available on YouTube (Le Boursicaud et al., 2016). There was a 3-5\% velocity error for a $15-30 \mathrm{~cm}$ water level bias, which was the largest source of error in the analysis. Recently, a long-term discharge monitoring project of a mountain stream with LSPIV applications used an automated detection of the water level heights (Stumpf et al., 2016). This method still poses a problem for the highly irregular debris-flow surfaces. However, considering the low percent error, approximate heights should be feasible for surface velocity. Laser profile scanners were also used in LSPIV applications for measuring debris-flow velocities with direct comparisons of flow heights, providing accurate discharge measurements and analysis of the flow dynamics (Jacquemart et al., 2017).

To our knowledge, the application of LSPIV on debris flows from video images has not been deeply investigated, whereas it could provide direct measurements to quantify rheological behaviour of debris flows. Our objective is to test the LSPIV method on debris flows using available cameras in a monitored catchment in the Italian Alps (Gadria catchment; Fig. 1). The aims of this work are to explore (1) the spatial and temporal variations within one study reach of debris-flow surges that occurred in the period 2013-2015, (2) a detailed analysis of an individual surge dynamic, (3) the quantification of a horizontal turbulence index (influenced by rheological parameters) from the directional variation of vectors, and (4) the limitations/perspectives of the LSPIV for further development.

\section{Setting}

The Gadria catchment is situated in the Venosta (Vinschgau) Valley (South Tyrol) in the eastern Italian Alps (Fig. 1a) and features a drainage area of $6.3 \mathrm{~km}^{2}$ (between 1394 and $2945 \mathrm{~m}$ a.s.1.), with an average slope of $79.1 \%$. The source area consists of highly deformed and fractured metamorphic rock, thick glacio-fluvial deposits, and steep topography, which makes the catchment prone to rockfall, landslides, avalanches, and debris flows. The topographic settings of the catchment ensure an effective connectivity of sediment between the source areas (D'Agostino and Bertoldi, 2014) and the downstream channel reaches (Cavalli et al., 2013). Debris flows occur in the summer and are usually triggered by spatially limited convective storms. The mean volume of the debris flows observed between 1979 and 2013 is $14000 \mathrm{~m}^{3}$ (median $8000 \mathrm{~m}^{3}$; Aigner et al., 2015). The sediment yield of the Gadria catchment between 2005 and 2011, a period with normal frequency and magnitude of debris flows, was computed through DEM differencing (Cavalli et al., 2017) and amounted to about $5200 \mathrm{~m}^{3} \mathrm{~km}^{-2} \mathrm{yr}^{-1}$. Instrument monitoring of the Gadria catchment began in 2011. For detailed information on the study site and monitoring set-up, refer to Comiti et al. (2014).

Two cameras are alongside a sediment trap (retention basin) near the alluvial fan apex, one looking upstream (Cam 1) and the other looking down at a more perpendicular angle to the flow (Cam 2). The third camera (Cam 3) is in the next reach upstream from the sediment trap at a closer proximity to the flow (Fig. 2). These three cameras are connected to a cabin equipped with power supply and a server (8 TB storage capacity) collecting all the monitoring data. Cam 4 is in an upstream ravine and it is triggered by a rain gauge when there is at least $1 \mathrm{~min}$ of rainfall. For this study, we focused on the application of LSPIV using only one of the four MOBOTIX M12 video cameras, Cam 2.

We attempted to utilize the other cameras for LSPIV application, but Cam 1 and Cam 3 were too close with an upstream view to measure the large scale of the debris flow. Within the area of high incidence angle of the images, the number of reference points is restricted. There is little spatial coverage, 


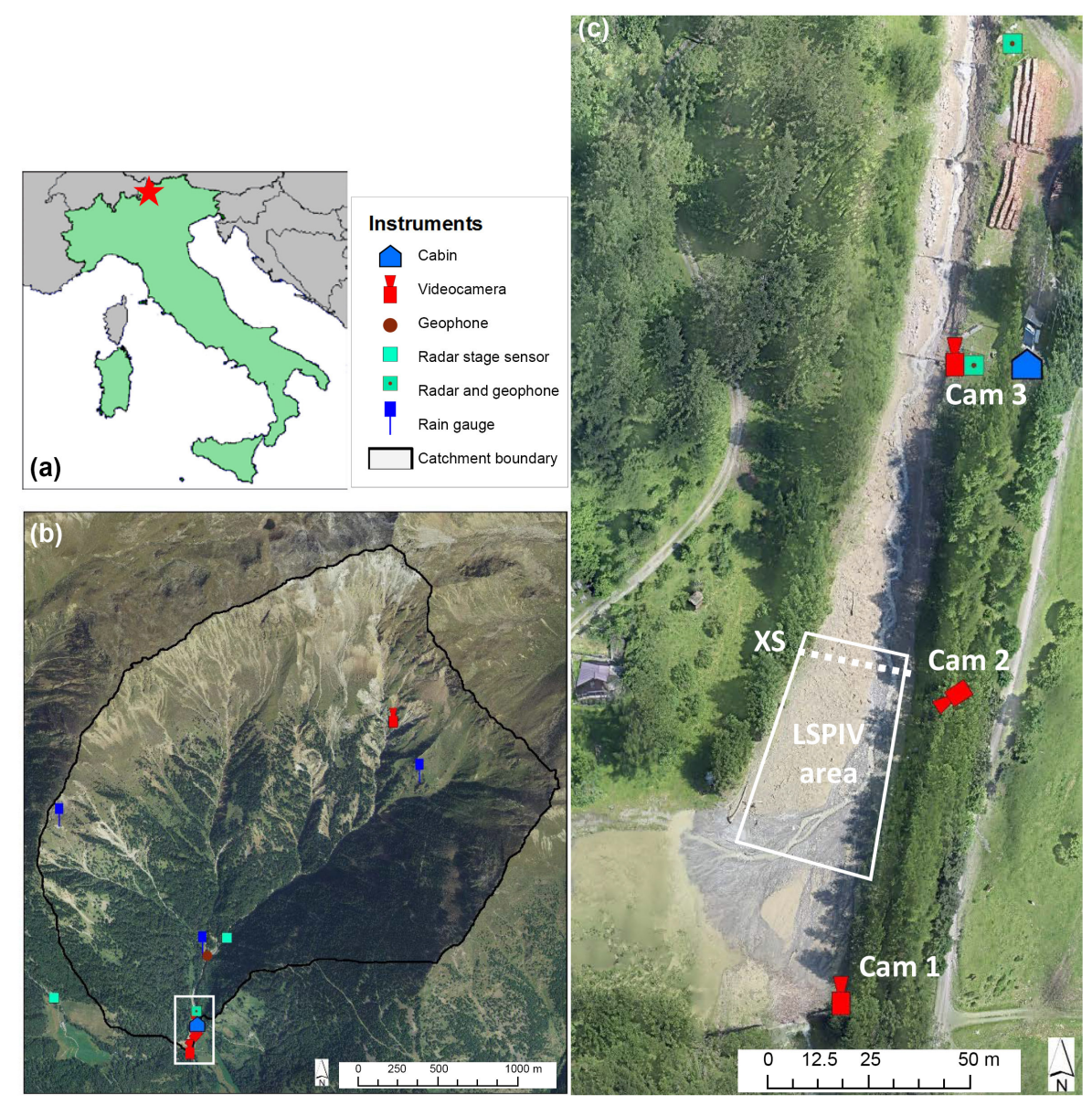

Figure 1. Gadria catchment is situated in the Venosta (Vinschgau) Valley, South Tyrol, Italian Alps (a, red dot). The catchment is equipped with rain gauges, radar stage sensors, video cameras, and geophones (b). At the end of the catchment (c) is a sediment retention basin where most of the instrumentation is kept; XS: cross sections used in LSPIV measurements.

and there was too much pooling of water in front of Cam 1 located at the dam. Cam 2 was the best option because it was located higher above the levee (10-52\% incidence angle), $12-46 \mathrm{~m}$ from the LSPIV area, and had an orientation more perpendicular to the flow path. Cam 4 was problematic due to the unchannelized nature of the recorded events, in combination with the relatively long distance between the camera and the moving sediment.

\section{Methods}

The LSPIV methods that we used are based on Le Boursicaud et al. (2016). The previous study tested the LSPIV method on a pulsating flash flood in the French Alps recorded from a GoPro. The videos were treated for photo stitching and format conversion using freeware and the LSPIV calculation on the freeware Fudaa-LSPIV (Le Coz et al., 2014; https://forge.irstea.fr/projects/fudaa-lspiv/files).

\subsection{Video treatment}

The M12 Mobotix security camera that we used is an IP camera (resolution $1689 \times 1345$ pixels) with a fisheye lens. At night spotlights are activated during rainfall. This camera has limiting features such as an automatic adjustment for shutter speed with illumination, and therefore the frame per second cannot be fixed. This initially was a problem since our aim was to constantly have 10 frames per second (fps). During recording of the flow events, the frequency reduced to 2-3 fps because of the poor lighting during the storms. We needed a standard frame rate for LSPIV calculations. Therefore we subsampled the images to the minimum frame rate of each flow event (Table 1).

Also, since the camera had a fisheye lens, significant distortion correction was required. A checkerboard pattern image from the camera was used in a free software Hugin (http://hugin.sourceforge.net), which has a tool for distortion correction. This was then applied to all the video imagery and converted to an ASCII greyscale format using batch process- 
Table 1. LSPIV parameters used for the 2013, 2014, and 2015 events.

\begin{tabular}{|c|c|c|c|}
\hline & 2013 & 2014 & 2015 \\
\hline resolution & \multicolumn{3}{|c|}{$5 \mathrm{~cm}$ pixel $^{-1}$} \\
\hline $\begin{array}{l}\text { alignment error near } \\
\text { the flow plane }\end{array}$ & $3-10 \mathrm{~cm}$ & $4-7 \mathrm{~cm}$ & $8-13 \mathrm{~cm}$ \\
\hline \multirow{3}{*}{$\begin{array}{l}\text { \# reference points } \\
\text { interrogation area } \\
\text { search area (pixels) }\end{array}$} & 13 & 13 & 14 \\
\hline & \multicolumn{3}{|c|}{26 pixel (1.3 m) } \\
\hline & \multicolumn{3}{|c|}{$\begin{array}{l}75-100 \text { down; } 5 \text { up; } \\
35-50 \text { left; } 30-50 \text { right }\end{array}$} \\
\hline time step & $0.333 \mathrm{~s}$ & $0.5 \mathrm{~s}$ & $0.5 \mathrm{~s}$ \\
\hline grid & \multicolumn{3}{|c|}{$0.4-1.2 \mathrm{~m}$} \\
\hline area & \multicolumn{3}{|c|}{$28-35 \mathrm{~m}$ long and $7-32 \mathrm{~m}$ wide } \\
\hline
\end{tabular}

ing in the XNview freeware (www.xnview.com). This used to be necessary for the Fudaa software; however the more current version can now handle jpeg- and tiff-coloured formats.

\subsection{Reference points using Structure from Motion Photogrammetry}

High-resolution coloured point clouds from Structure from Motion (SfM) surveys were found to be very useful for matching reference points with the video images (Fig. 2a). In active debris-flow channels, permanent points are difficult to keep within the active area, and with oblique angled cameras, there needs to be as many reference points as possible. The sediment trap and channel were surveyed before and after flow events. We did this by walking up and down the banks with a camera mounted on a $5 \mathrm{~m}$ pole with georeferenced targets (measured by total station) distributed throughout the channel and trap. The SfM photogrammetry using AgiSoft ${ }^{\circledR}$ Photoscan (e.g. Westoby et al., 2012; Javernick et al., 2014; Piermattei et al., 2015) was used to generate high-resolution coloured point clouds (1300-2900 pts $\mathrm{m}^{-3}$ ) with $2 \mathrm{~cm}$ alignment error (using an iterative closest point algorithm on permanent features) making it a reliable spatial and visual reference. For the LSPIV purposes, the point clouds were rotated to make an approximate horizontal flow plane ( $5^{\circ}$ rotation) to reduce any added spatial error. These flow planes are easily visible in the coloured point clouds with distinct mud lines.

\subsection{LSPIV calculations using Fudaa}

For orthorectifying the video images, targets and natural features were used as reference points for matching between the SfM point cloud (both pre-event and post-event) and video imagery (Fig. 2a, b). Corners of rocks next to the flow line were typically used on each side of the channel, and sometimes exposed stable rocks within the channel. Alignment errors of the reference points (Table 1) in the orthorectification process of Fudaa-LSPIV increase going down and across the channel according to the camera's oblique angle. The flow plane elevation was also measured by averaging matched features touching the flow line in the post-event point cloud. This is the best estimate of the rough variable surface of the flow height. The unsteady flows also required the fronts and tails to be separated to redefine the flow plane elevation, which is known to be the largest source of error for LSPIV (Le Boursicaud et al., 2016).

The interrogation area (IA; Fig. 2c) is the boundary for calculating a correlation coefficient, which needs to be representative of the flow velocity (Fig. 2d). It should find the travel distance between each time step of general features in the flow, not individual particles, which is unrealistic in irregular flows with sediment rolling and when they are continuously being submerged. We used a $26 \times 26$ pixel $(1.3 \mathrm{~m} \times 1.3 \mathrm{~m})$ interrogation area for calculating the correlation coefficient and a search area (SA; Fig. 2c) of 75-100 pixels (3.75-5 m) downstream, $60-100$ pixels $(3-5 \mathrm{~m})$ wide, and a small 5-pixel segment upstream to capture flow towards the banks.

To have a good spatial distribution of the flow with a manageable data set, we selected a grid with an approximate spacing of $0.7 \mathrm{~m}$ (varies with flow width; Fig. 2c). Within the Fudaa software, we filtered any velocities with a correlation coefficient less than $0.5-0.6$ for a robust data set (Fig. 2d). The velocity vectors were transferred into ArcGIS and overlaid on the corresponding orthorectified image for manual cleaning. Noisy data can occur outside of the flow area because of rain, wind, or changing light reflection on wetted surfaces. The manual treatment of the vectors was also necessary for outlining and separating the different surges and parts of the surge (front and tail) travelling through the study reach.

The spatial distribution of velocity vectors covering the reach provided an opportunity to examine their variation (direction and velocity fluctuation) to characterize the turbulence of the various debris-flow surges (Costa, 1984). Since our LSPIV method is two-dimensional, we define it as the horizontal turbulence index according to directional variation $\left(T_{\mathrm{d}}\right)$ and velocity variation $\left(T_{\mathrm{v}}\right)$. We measure the turbulence $\left(T_{\mathrm{d}}\right.$ and $\left.T_{\mathrm{V}}\right)$ by taking the standard deviation of vector orientations $\left(T_{\mathrm{d}}\right)$ and velocities $\left(T_{\mathrm{V}}\right)$ in three adjacent cross sections for three time steps. The given segment of cross sections can be used to examine the changing characteristics of the surges rather than the spatial distribution. Therefore, small $T_{\mathrm{v}}$ and $T_{\mathrm{d}}$ should characterize laminar flow conditions, and higher values should be associated to more turbulent flows.

The LSPIV results were taken from cross section XS (Fig. 1c) to obtain accurate comparisons of debris-flow surges. This is the most stable cross section before the widening in the sediment trap. It is also the closest and most perpendicular view from the camera, resulting in the most accurate LSPIV calculations. The LSPIV study reach experienced important deposition and remobilization during the debris- 

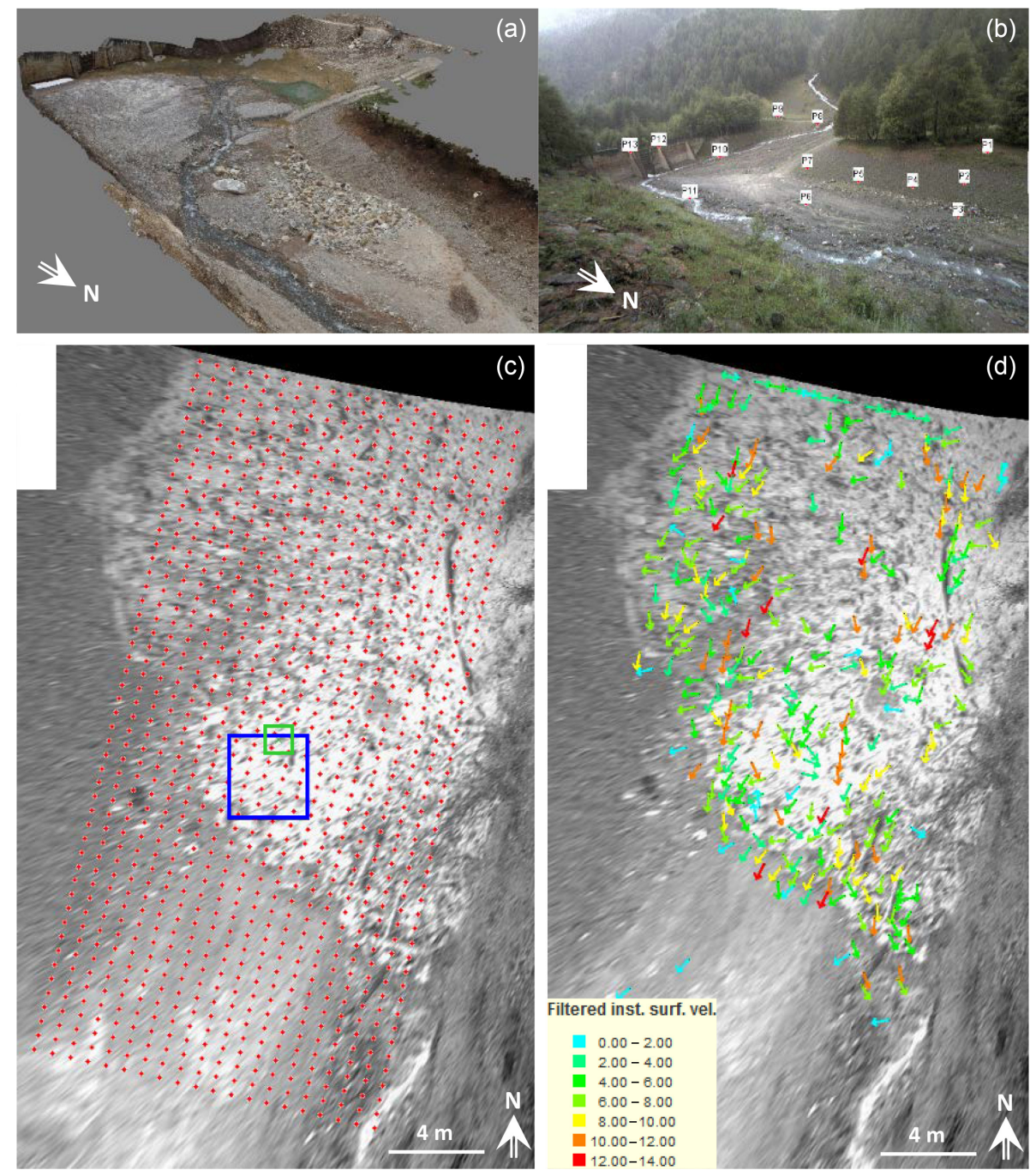

Figure 2. Example of (a) a SfM point cloud used as a post-event reference, (b) the undistorted camera image with the reference points, (c) the orthorectified image during the 2013 debris-flow front with the sampling grid, interrogation area (IA; green) and the search area (SA; blue), and (d) the instantaneous surface velocity vectors.

flow surges; therefore we did not attempt to measure the discharge rates.

\section{Analysed events}

In the 2011-2015 time span there have been four important events (Table 2; Fig. 3). The 2011 event was complex, with the first and most important surge consisting of a hyperconcentrated flow and only Cam 1 and Cam 3 were operational at the time (Fig. 3). Therefore, LSPIV was not performed; measurements of flow velocity were performed manually (ratio of the time interval between the passage of the front and the distance between the two radar sensors) and by means of cross-correlation between the stage recordings (Comiti et al., 2014). There were no significant events in 2012.
The 2013 event featured one important surge, a very typical debris-flow formation with a bouldery front and a slurrylike tail. The singular surge provided a convenient detailed analysis of the front, intermediate stage (transition from front to tail), and the tail (described later).

The 2014 event had a small preliminary surge (pre-surge) and four debris-flow surges (S1-S4) passing through the study reach. It should be noted that there was a discontinuous surge that stopped just upstream of the LSPIV measurements before the first measured surge passed through the reach. The first two measured surges were large enough to distinguish the front (S1 and S2) and tail (S1 tail S2 tail) and the latter two were too small and were kept undivided (S3 and S4). There seemed to be a higher water content with longer sustained fronts (compared to 2013). The S4 was unusually fast 
Table 2. Results of averaged LSPIV measurements, visual feature measurements on orthorectifed images, and radar sensors (70-150 m upstream from the LSPIV section) for identifiable surges in 2011, 2013, 2014, and 2015 (no events occurred in 2012).

\begin{tabular}{|c|c|c|c|c|c|c|c|c|c|c|}
\hline \multirow[t]{2}{*}{ Event } & \multirow[t]{2}{*}{ Surge } & \multirow[t]{2}{*}{ Time } & \multicolumn{4}{|c|}{ LSPIV } & \multicolumn{2}{|c|}{ Visual } & \multicolumn{2}{|c|}{$\begin{array}{l}\text { Radar sensors ( } 70 \text { and } 150 \mathrm{~m} \\
\text { upstream from LSPIV) }\end{array}$} \\
\hline & & & $\begin{array}{l}\text { velocity } \\
\left(\mathrm{m} \mathrm{s}^{-1}\right)\end{array}$ & $\begin{array}{r}\text { width } \\
(\mathrm{m})\end{array}$ & $\begin{array}{l}T_{\mathrm{d}} \\
\left({ }^{\circ}\right)\end{array}$ & $\begin{array}{r}T_{\mathrm{V}} \\
\left(\mathrm{m} \mathrm{s}^{-1}\right)\end{array}$ & $\begin{array}{r}\text { sediment } \\
\text { concentration }\end{array}$ & $\begin{array}{l}\text { velocity } \\
\left(\mathrm{m} \mathrm{s}^{-1}\right)\end{array}$ & $\begin{array}{l}\text { velocity } \\
\left(\mathrm{m} \mathrm{s}^{-1}\right)\end{array}$ & $\begin{array}{r}\text { average height } \\
\text { (m) }\end{array}$ \\
\hline 2011 & HF surge & $18: 00-18: 30$ & - & - & - & - & low & - & 2.6 & \\
\hline \multirow[t]{3}{*}{2013} & S1 front & $17: 23: 10-17: 23: 26$ & 4.4 & 19 & 24.5 & 2.7 & high & 4.4 & 5.7 & 1.9 \\
\hline & $\mathrm{S} 1$ inter. & $17: 23: 35-17: 23: 42$ & 3.1 & 18 & 15.2 & 1.3 & medium & 2.4 & - & 1.6 \\
\hline & $\mathrm{S} 1$ tail & $17: 23: 43-17: 24: 05$ & 1.9 & 17 & 24.6 & 1.3 & medium & 2.6 & - & 1.0 \\
\hline \multirow[t]{7}{*}{2014} & Pre-surge & $17: 13: 45-17: 15: 13$ & 3.2 & 7 & 33.8 & 2.2 & low & 2.7 & - & 0.4 \\
\hline & $\mathrm{S} 1^{*}$ & $17: 22: 01-17: 22: 17$ & 4.6 & 23 & 36.0 & 2.8 & medium & 5.6 & 5.3 & 1 \\
\hline & S1 tail* & $17: 22: 20-17: 22: 49$ & 4.2 & 13 & 32.6 & 3.1 & medium & 4.4 & 4.8 & 0.5 \\
\hline & $\mathrm{S} 2$ & $17: 25: 43-17: 26: 04$ & 3.1 & 22 & 32.3 & 2.8 & high & 3.3 & 4.1 & 0.9 \\
\hline & S2 tail & $17: 26: 10-17: 27: 00$ & 2.9 & 15 & 34.1 & 2.6 & high & 2.8 & 3.6 & 0.7 \\
\hline & $\mathrm{S} 3$ & $17: 29: 24-17: 29: 40$ & 3.9 & 14 & 32.3 & 3.3 & high & 4.4 & 4.8 & 0.9 \\
\hline & S4 (wave) & $17: 30: 13-17: 30: 21$ & 6.2 & 8 & 31.3 & 4.2 & low & 6.9 & 3.5 & 0.7 \\
\hline \multirow[t]{5}{*}{2015} & S1 & $17: 16: 52-17: 17: 15$ & 5.6 & 14 & 33.2 & 3.0 & low & 4.9 & - & 0.8 \\
\hline & $\mathrm{S} 2$ & $17: 20: 05-17: 21: 02$ & 2.5 & 17 & 30.7 & 2.8 & high & 3.0 & 3.5 & 0.8 \\
\hline & S3 & $17: 23: 30-17: 24: 01$ & 2.2 & 22 & 29.2 & 2.5 & high & 1.5 & 3.5 & 1.25 \\
\hline & $\mathrm{S} 4$ & $17: 24: 25-17: 25: 12$ & 0.6 & 20 & 21.5 & 1.1 & very high & 0.7 & - & 0.6 \\
\hline & S5 & $17: 26: 54-17: 27: 39$ & 0.8 & 16 & 9.4 & 0.6 & very high & 1.0 & - & 0.8 \\
\hline
\end{tabular}

* The first actual debris-flow surge stopped between the LSPIV and the radar. It remobilized with S1.

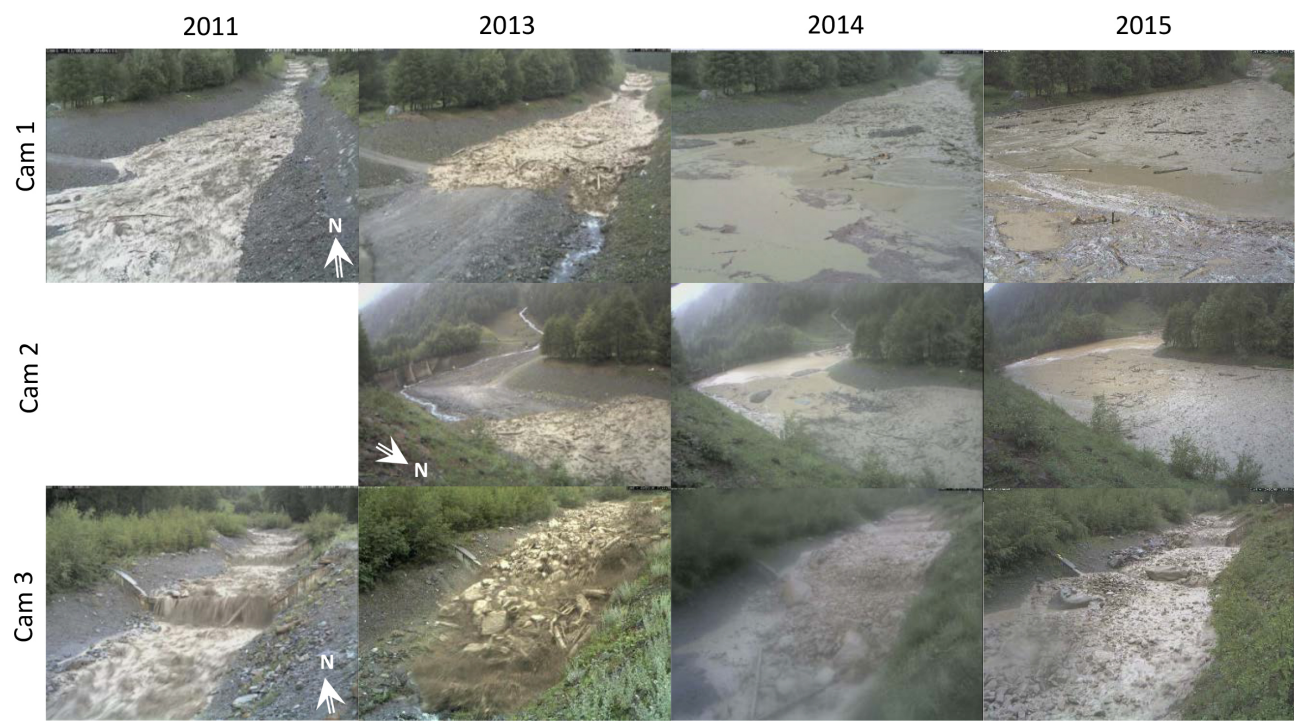

Figure 3. Views of the three cameras during the 2011, 2013, 2014, and 2015 debris flows. Cam 2 was selected for the LSPIV application due to best positioning.

and behaved more like a wave passing through the filled-up sediment trap of highly saturated deposit.

The 2015 event was especially interesting because of the variable rheology of the surges. High-intensity rainfall covered the entire catchment, triggering many different source areas. The first surge (S1) had little sediment but carried a lot of large woody debris. S2 was a slower muddier flow; however cobbles and boulders were also transported. S3 was a larger and even slower muddy flow, carrying boulders, cobbles, and large woody debris. S4 is the slowest surge and a more visco-plastic flow, but still carries cobbles. S5 is similar to $\mathrm{S} 4$ but carried fewer cobbles. In between these surges the low-flow material stopped. The visco-plastic material waited for the next surge to push it forward. A low steady muddy flow continued for another $30 \mathrm{~min}$ with smaller surges. How- 
ever, the sediment trap filled up, creating a saturated pool of sediment and making it difficult for surges to pass through.

\section{Results}

\subsection{Surface flow velocities}

LSPIV results of the three analysed debris flows were extracted from the upstream cross section of the LSPIV reach (XS in Fig. 1c). This makes surge comparisons more accurate because it is located in a more stable and confined location, rather than in the open sediment trap that fills up during the events. Mean surge velocities ranged from 0.6 to $6.2 \mathrm{~m} \mathrm{~s}^{-1}$, velocity variation turbulence $\left(T_{\mathrm{v}}\right)$ from 0.6 to $4.2 \mathrm{~m} \mathrm{~s}^{-1}$, and directional variation turbulence $\left(T_{\mathrm{d}}\right)$ from 9.4 to $36.0^{\circ}$ (Table 2; Fig. 4). The instantaneous velocities for the 2013 event have smaller variations compared to the other events. The minimum recording frequency was 3 fps for 2013 and $2 \mathrm{fps}$ for 2014 and 2015 because of the available light during the storms. The highest velocity (2014 S4) had a significantly higher $T_{\mathrm{V}}$, which is expected for a wave passing through slurry.

The LSPIV velocities seem fairly accurate considering the low camera frequency (2-3 fps), camera angle, $5 \mathrm{~cm} \mathrm{pixel}^{-1}$ resolution, and the unsteadiness of the flows. Their average velocities at a given cross section were compared with manual measurements of identifiable features on the same orthorectified images (feature picking) to validate the LSPIV cross-correlation matching (Table 2; Fig. 5). The LSPIV has a slight underestimation with a mean difference of $-0.1 \mathrm{~m} \mathrm{~s}^{-1}$ and a standard deviation of $0.54 \mathrm{~m} \mathrm{~s}^{-1}$. The LSPIV estimates are, however, more robust because of the large sample sizes and the feature picking does not always represent the flow velocity accurately.

The LSPIV velocities are also compared with the velocities measured by the radar sensors $70-150 \mathrm{~m}$ upstream (located in Fig. 1). Given the downstream decrease in velocity, the agreement is satisfactory, with a mean difference of $-0.9 \mathrm{~m} \mathrm{~s}^{-1}$ and a standard deviation of $0.25 \mathrm{~m} \mathrm{~s}^{-1}$ (Table 2; Fig. 5). Not all of the surges could be traced from the radar sensors to the LSPIV reach; rather they will stop and be pushed by the next surge. This is especially the case with the visco-plastic surges in 2015.

\subsection{Pattern of flow velocities from the 2013 debris flow}

The LSPIV results can be presented and analysed in several different ways. For the 2013 debris flow, we show the map view of the average velocities for the front (time of occurrence: 17:23:10-17:23:26), intermediate (17:23:3517:23:42), and tail (17:23:43-17:24:05; Fig. 6). Despite the simple shape of the 2013 debris-flow hydrograph (Comiti et al., 2014), it had a very interesting dynamic when entering the sediment trap. The front has high scattered average velocities covering the whole reach. The intermediate (transition

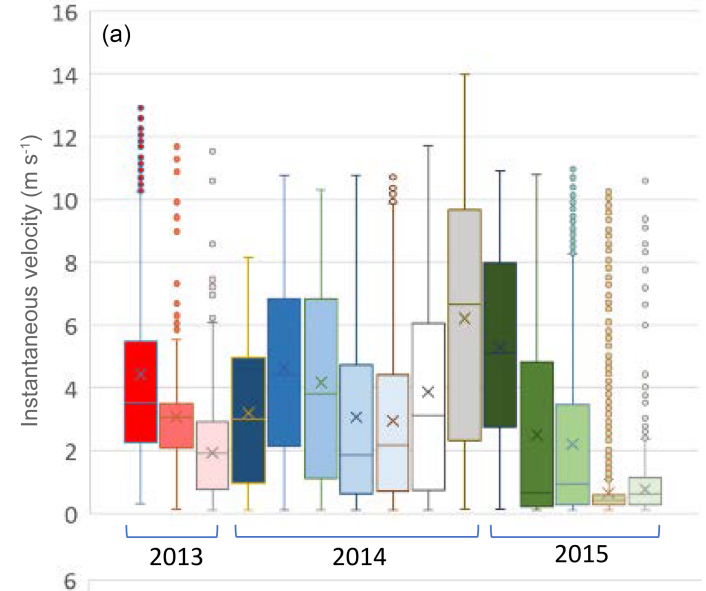

(b)
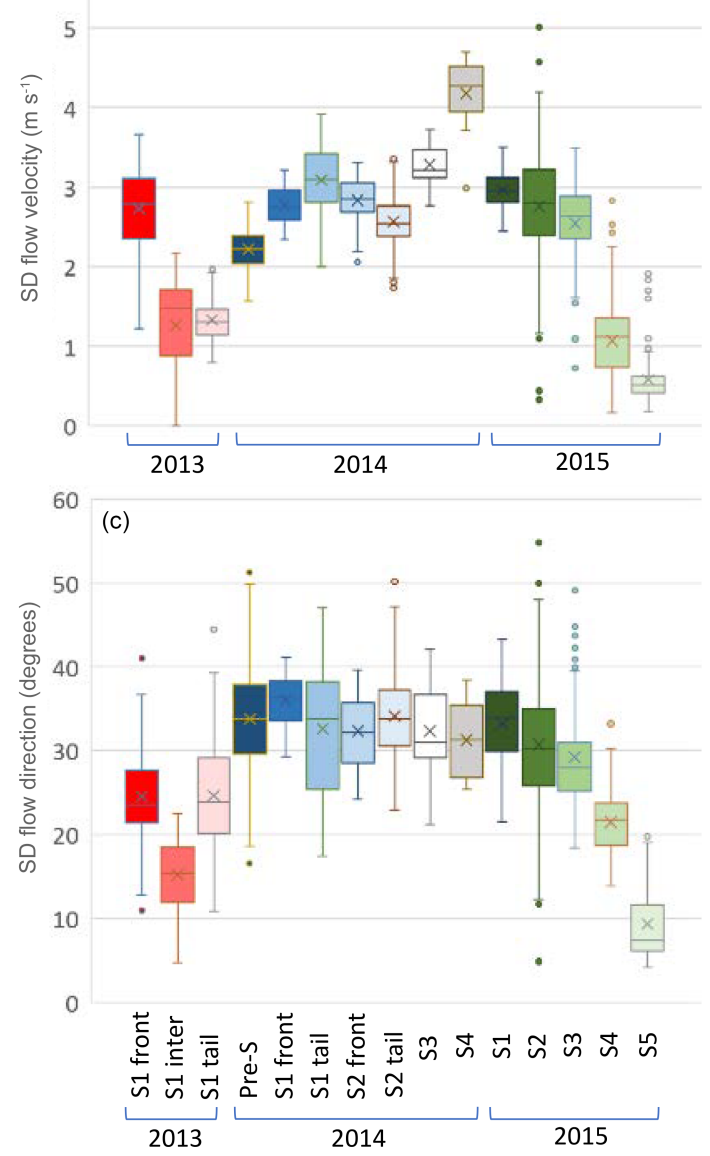

Figure 4. LSPIV velocity (a), velocity variation $\left(T_{\mathrm{V}} ; \mathbf{b}\right)$, and directional variation $\left(T_{\mathrm{d}} ; \mathbf{c}\right)$ comparisons for 2013, 2014, and 2015 surges located at the same cross section.

from front to tail) shows a distinct decrease in velocity with a more homogeneous distribution. Zero velocities correspond with the boulder-front deposition. The low-velocity tail becomes more confined travelling around the boulder front as a more laminar flow (Fig. 6c). 


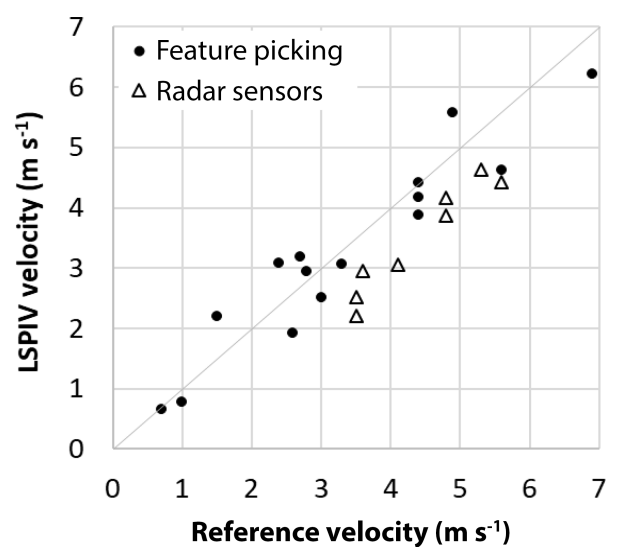

Figure 5. LSPIV velocities compared with velocities derived from feature picking in the orthorectified image sequences and radar sensors located 70-150 $\mathrm{m}$ upstream.

Three cross sections were examined to compare the velocity-time profiles of the event (Fig. 7b). The peak velocity at the front gradually decreases in duration. Nonetheless, when travelling through the reach the velocity remains relatively high. For the intermediate part, there is a distinct slump in velocity where the boulder front was deposited in cross section X2. The tail of the debris flow increases downstream. This is expected since the boulders confined the channel. In Fig. 7a, the LSPIV computation domain is overlaid on a map of the residual height, computed on the pre-event topography as the cell-by-cell difference between the SfM DEM and a smoothed mean DEM with cells that have a value equal to the mean of the neighbouring cells at a $5 \mathrm{~m}$ scale (Cavalli and Marchi, 2008). The residual height shows the general form of the channel revealing the smaller confined channel along the left bank and larger convex features covering the centre and right bank. These features correspond with the flow dynamics seen in Fig. 7 with the boulder front depositing on the higher convex features and with the water surge passing around the front and through the lower confined channel.

The longitudinal profile of the average velocities combined with the video imagery and multi-date topography (Fig. 8) distinctly show the boulder front depositing after the sudden decrease in local slope (down to a negative slope) and channel widening. The front average velocity remains constant even after the deposition of boulders. The intermediate part of the surge shows the correspondence of the decreased velocity and the deposition. The boulder deposit narrows the channel and therefore increases the velocity for the tail of the flow. The tail has an unusual increase in velocity at the downstream end, despite the local widening of the channel with decreasing velocity. Either there was a released plugging upstream or there was an important decrease in sediment concentration (upstream deposition).

Several studies observe peak velocities of debris flows located behind the boulder front (Pierson, 1986; Arattano and
Marchi, 2000; Suwa et al., 1993). The high concentration of the interlocking boulders creates a high frictional resistance and low mobility (Pierson, 1986; Suwa et al., 1993). Debrisflow channels typically have several reaches with important narrowing and widening, and naturally the velocity longitudinal profile must adjust to each channel reach. When the front is confined, boulders interlock and velocities are higher behind the front as previous studies showed. In our case, we observe the boulders unlocking, which creates more mobility where the peak velocity is at the very front of the flow. The boulders laterally deposit as a levee because of the decrease in transport capacity.

\subsection{Horizontal turbulence index}

Sediment concentration, viscosity, and yield strength are rheological parameters that can influence the turbulence and are commonly associated with flow resistance coefficients (e.g. Rickenmann and Recking, 2011). For all the surges in 20132015, we found that turbulence has a strong relationship with the surge velocity (Fig. 9), whereas flow heights and flow widths had much lower correlation with surge velocities. We compared both directional turbulence $\left(T_{\mathrm{d}}\right)$ and velocity turbulence $\left(T_{\mathrm{v}}\right)$ index measurements (see Sect. 3.3) to the empirical flow resistance equation for debris flows from Koch et al. (1998), described in Rickenmann (1999):

$C=\frac{V}{H^{0.3} S^{0.5}}$,

where velocity $(V)$ is the average LSPIV velocity for each surge, slope $(S)$ is constant, flow height $(H)$ is measured upstream from the radar sensors (thereby introducing an additional source of error), and $C$ is the flow resistance coefficient. The $T_{\mathrm{v}}$ clearly has a stronger correlation than the $T_{\mathrm{d}}$ when compared with $V$ and $C$ (Fig. 9). Based on the data analysed, the power-law equation that links $T_{\mathrm{V}}$ to the flow velocity $V$ through the coefficient $C$ is

$V=3.91 T_{\mathrm{v}}^{1.06} H^{0.3} S^{0.5}$.

However, more surges need to be measured to better define the function. The influence of spatial and temporal sampling resolutions also needs to be better understood for further application.

Sediment concentrations from visual estimates (Table 2) were used to classify these comparisons, which show a better correspondence with $T_{\mathrm{v}}$ than $T_{\mathrm{d}}$ when comparing it with $C$ for the debris-flow fronts. Sediment concentrations for the tails or waves did not correspond well, probably because of influences of fluid pressures from the front and the pooling of slurry in the sediment trap. Nonetheless, visual estimates of sediment concentrations are quite difficult, especially in highly turbulent conditions.

For some of the surges, boulders and logs can be seen rotating, resulting in misrepresentative flow directions and velocity fluctuations. Our interrogation area $(1.3 \mathrm{~m})$ for LSPIV 

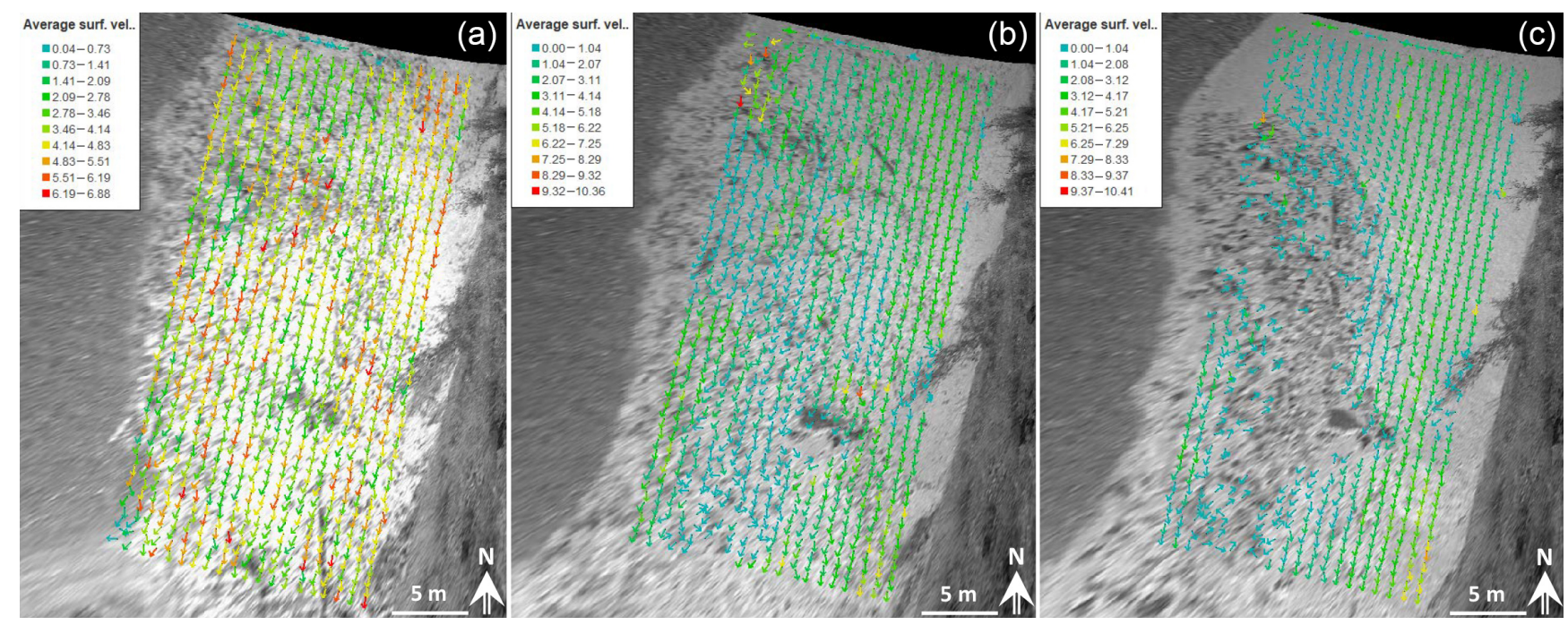

Figure 6. Average LSPIV velocities $\left(\mathrm{m} \mathrm{s}^{-1}\right.$ ) for the 2013 debris-flow front (a), intermediate (b), and tail (c).

(a)

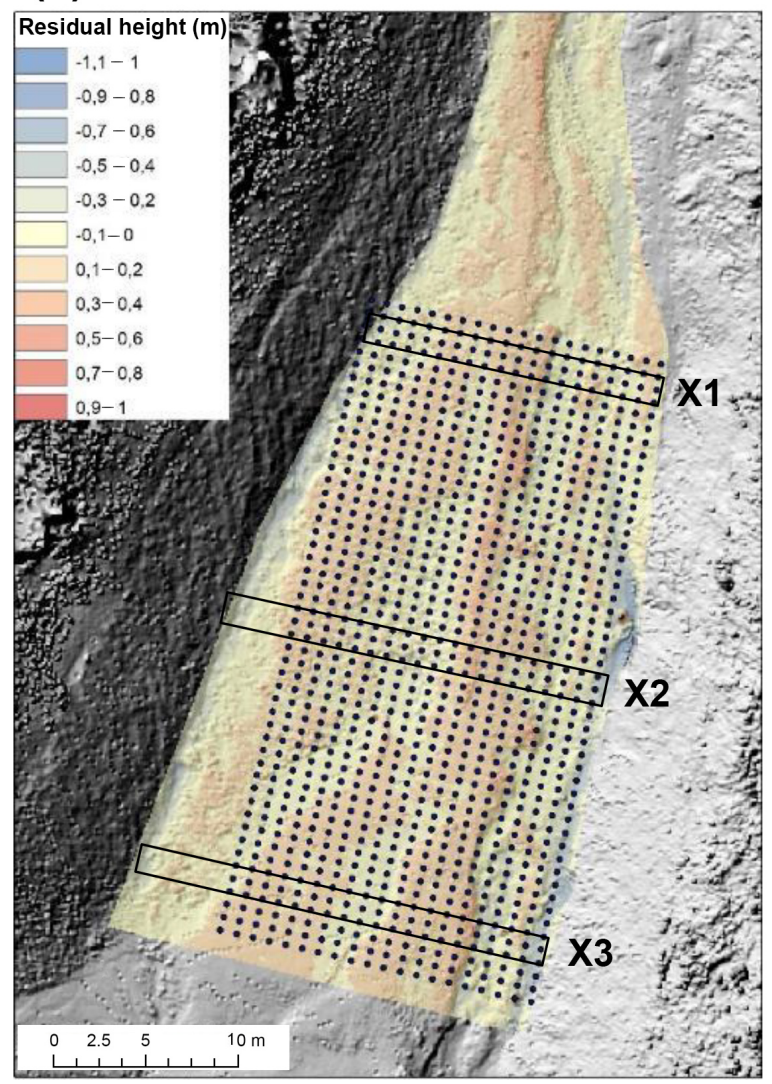

(b)
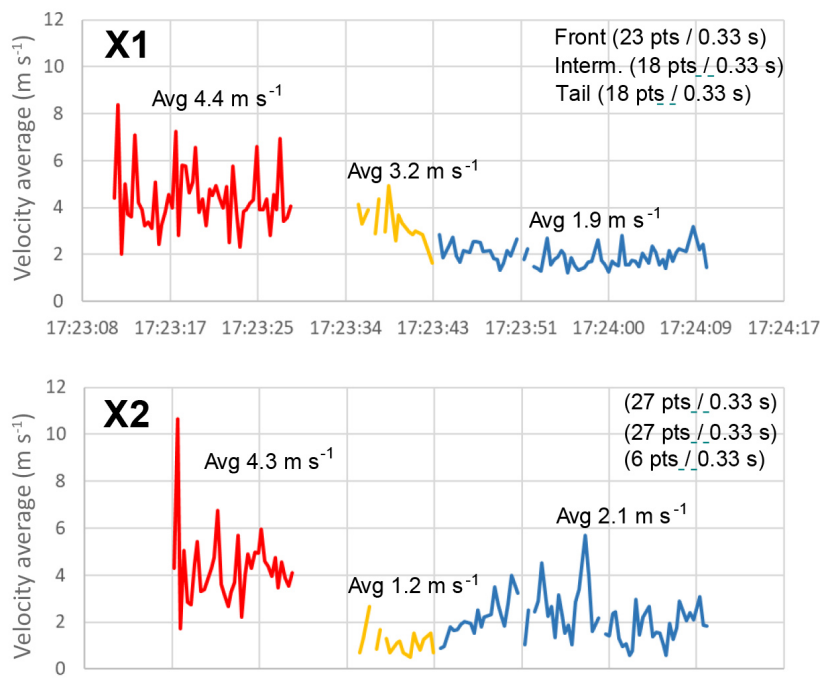

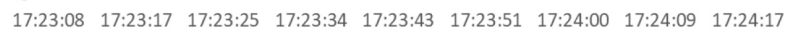

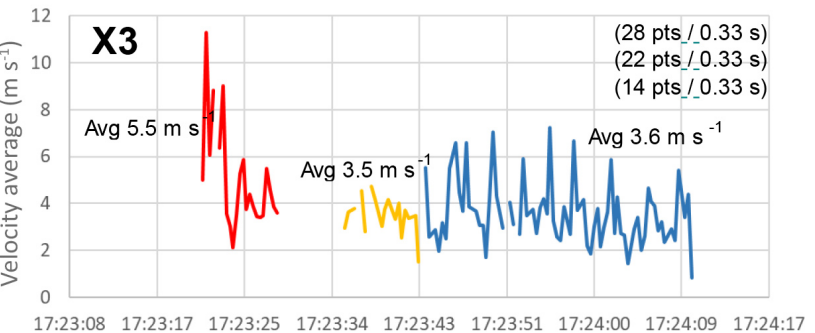

Figure 7. (a) Preliminary residual elevation of the channel bed at a $5 \mathrm{~m}$ scale. The grid of LSPIV calculations is shown with cross section X1-3 outlined; (b) 2013 debris-flow LSPIV velocity time series (3fps) at three cross sections (X1, X2, and X3) with red (front), yellow (intermediate), and blue (tail). The velocity variation mostly represents the turbulence; however, some noise can come from low point density. The time interruption between the front and intermediate was initially made in the LSPIV analysis to clearly distinguish the two. 


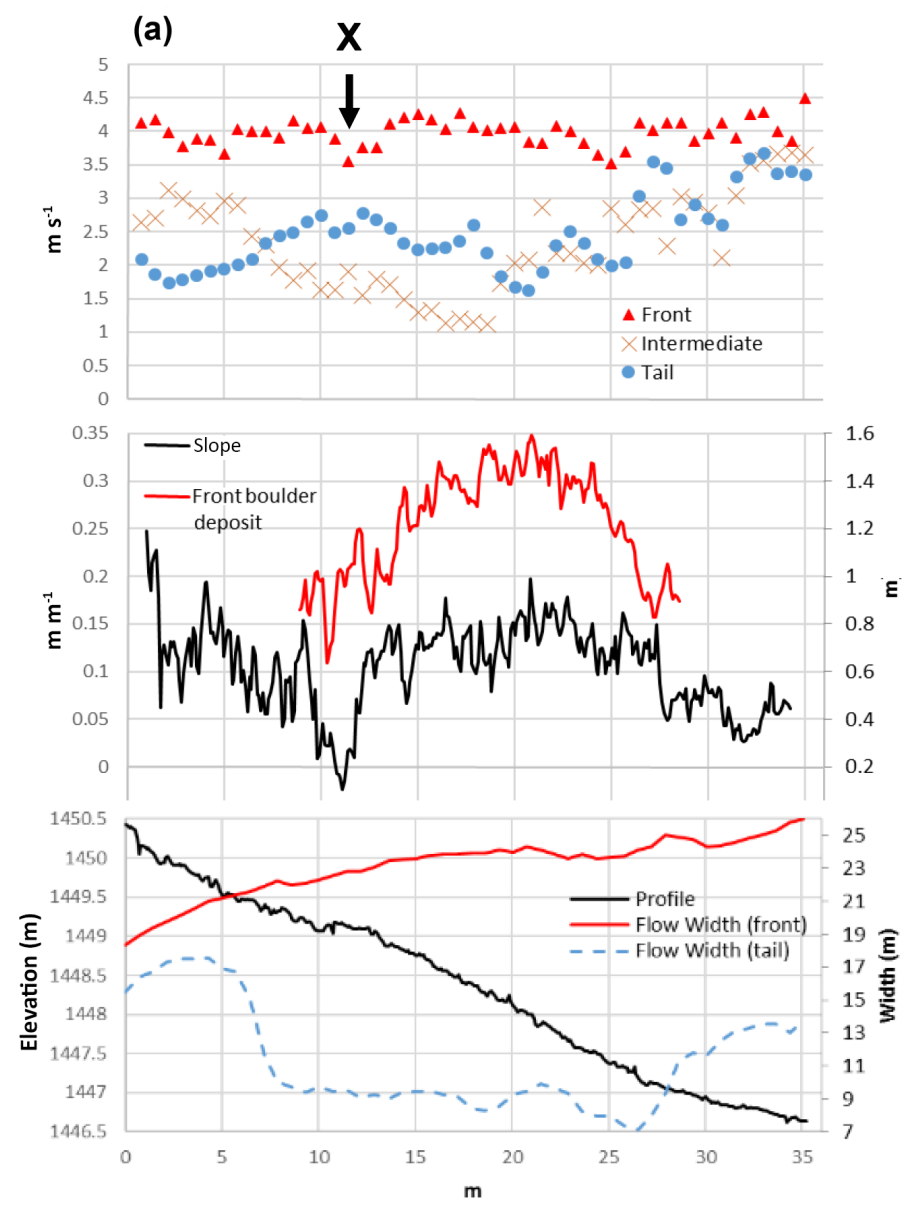

(b)

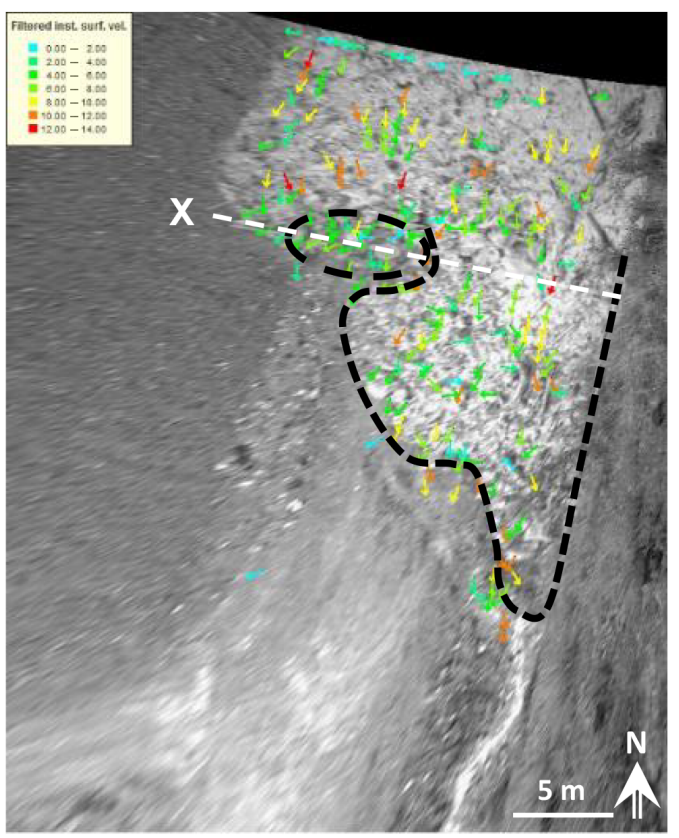

Figure 8. (a) The 2013 debris-flow LSPIV average velocity of the front (red), intermediate (yellow), and tail (blue) travelling down the long profile of the grid in Fig. 7. Local slope and the boulder front deposit (from multi-date SfM) are also plotted along the distance (centre) as well as pre-event elevation and flow width of both the front and tail (bottom). At the cross section X, the boulder front is seen to deposit, while the watery surge passes around it (b), which gives constant peak velocity at the front of the surge (despite the front deposition).

calculations was aimed to characterize the general flow characteristics where these misrepresentations are either too detailed or have little influence on the high sampling of the LSPIV method. Higher image resolution and camera speed might give further insight into boulder dynamics and log jamming.

\section{Conclusions}

We have presented LSPIV-derived velocities for three debrisflow events in the Gadria channel, for a total of 11 surges and these velocities were compared with manual measurements on the orthorectified imagery (mean difference of $-0.1 \mathrm{~m} \mathrm{~s}^{-1}$ ) and upstream radar sensors (mean difference of $-0.9 \mathrm{~m} \mathrm{~s}^{-1}$ ). LSPIV appears to be a reliable method for measuring velocities of such flows, and to the best of our knowledge, this is one of the first studies on the topic. The variation of vectors from the LSPIV was introduced as an index of hor- izontal turbulence according to directional variation $\left(T_{\mathrm{d}}\right)$ and velocity variation $\left(T_{\mathrm{v}}\right)$.

Within the studied reach, debris flows varied in velocity and turbulence among different events, among individual surges within an event, and even within each surge. Several contributing factors can explain the observed variability, for instance in rainfall, activation of variable source areas, channel storage levels, check-dam failures, boulder and log jamming, and the complex interactions between the channel dynamic and the flow in general. For example, the 2015 event distinctly had the largest variation of surge velocities and turbulence that most likely caused by the burst of rainfall distributed over most of the catchment, which in turn activated more source areas than other events. The 2013 debris flow showed that a gentle relief in the channel opening can influence the front material deposition but not decrease the mean front velocity because of the water surge passing through and around the unlocking boulders. A strong power-law relationship is found between velocity and the $T_{\mathrm{v}}$ as well as the flow 

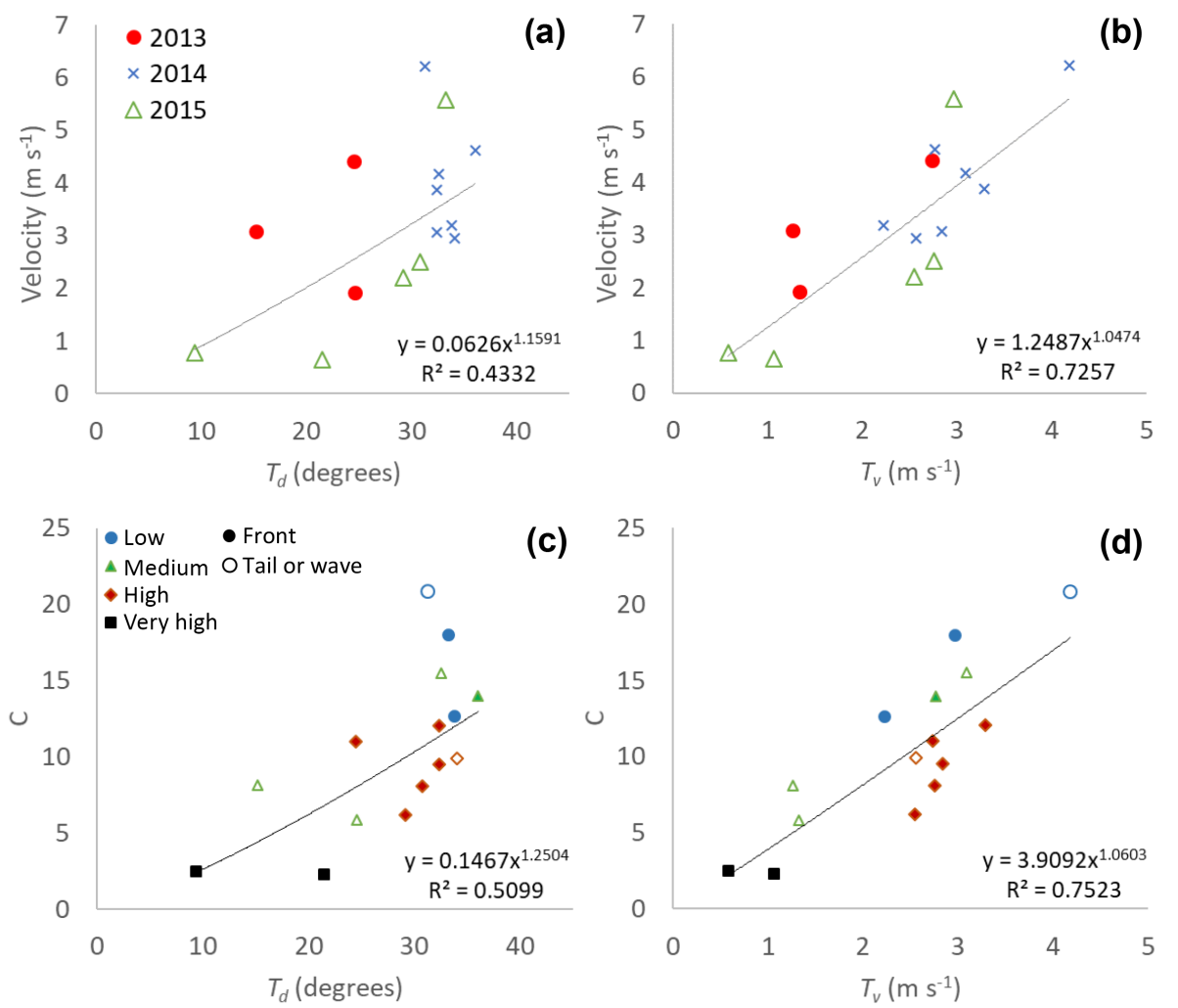

Figure 9. LSPIV average surge velocity (classified by events) are compared to (a) the directional turbulence index ( $\left.T_{\mathrm{d}}\right)$ and (b) the velocity turbulence index $\left(T_{\mathrm{V}}\right)$. The flow resistance coefficient ( $C$; Eq. 1; classified by visually estimated sediment concentrations) is compared to (c) $T_{\mathrm{d}}$ and (d) $T_{\mathrm{v}}$ (from Table 2).

resistance coefficient $C$ in the empirical equation of Koch et al. (1998). We propose that the $T_{\mathrm{v}}$ measurement improves the flow resistance coefficient for estimating velocity and $T_{\mathrm{d}}$ gives a better representation of sediment concentration.

The application of LSPIV on debris flows has shown to be very effective but there still needs to be a better understanding of the spatial and time resolutions and the influence of slope. Some suggestions can be made for this type of monitoring, such as (1) being sure that the minimum frame rate of the IP camera is high enough to capture the movement ( $2 \mathrm{fps}$, depending on the flow velocity) or use a fixed frame rate from an analog camera; (2) locating the cameras to a stable reach with high viewing positions that are perpendicular to the flow; and (3) overlapping the study area directly over stage sensors for discharge measurements for proper analysis of turbulence. Further studies can also involve calibrating geophones with the turbulence measurements, which are more easily distributed in the field.

Further research on LSPIV-derived velocity and turbulence needs to address the influence of confinement and roughness of the channel bed. Debris-flow channels have intermediate and large-scale roughness that make flow velocities and turbulence more variable as flow heights decrease (Rickenmann and Recking, 2011; Ferguson, 2012). Large- scale roughness can effect the confinement of the channel such as a large boulder or a debris-flow levee. Pre-event highresolution elevation models and their residual heights and standard deviations at varying scales (Cavalli and Marchi, 2008) will provide better insight into spatial distribution of debris-flow velocities when they are directly compared with LSPIV measurements.

Data availability. The LSPIV data are not publicly available, but interested parties can contact the corresponding author. Video sharing will need permission from the Autonomous Province of BozenBolzano.

Competing interests. The authors declare that they have no conflict of interest.

Acknowledgements. Funding for this research came from the research project "Kinoflow" funded by the Autonomous Province of Bozen-Bolzano. The debris-flow monitoring station of Gadria catchment is managed by the Civil Protection Agency of the Autonomous Province of Bozen-Bolzano. A preliminary analysis of the debris-flow hydrograph conducted by Vincenzo D'Agostino 
and Francesco Bettella (Department TeSAF, University of Padova) helped to interpret the 2014 event. We also thank Alexandre Hauet (EDF-DTG Grenoble), who provided guidance and advice for the Fudaa-LSPIV application.

Edited by: Andreas Günther

Reviewed by: Christoph Graf and one anonymous referee

\section{References}

Aigner, J., Habersack, H., Rindler, R., Blamauer, B., Wagner, B., Schober, B., Comiti, F., Dell'Agnese, A., Engel, M., Liébault, F., Bel, C., Bellot, H., Fontaine, F., Piegay, H., Benacchio, V., Lemaire, P., Ruiz-Villanueva, V., Vaudor, L., Cavalli, M., Marchi, L., Crema, S., Brardinoni, F., Bezak, N., Rusjan, S., Mikoš, M., Abel, J., Becht, M., Heckmann, T., Rimböck, A., Schwaller, G., Höhne, R., Cesca, M., Vianello, A., Krivograd Klemenčič, A., Papež, J., Lenzi, M. A., Picco, L., Moretto, J., Ravazzolo, D., Jäger, G., Moser, M., Hübl, J., and Chiari, M.: Sed ALP - Sediment Management in Alpine Basins, WP5 Report - Sediment transport monitoring, 256 pp., available at: www.sedalp.eu (last access: 13 December 2017), 2015.

Arattano, M. and Grattoni, P.: Using a fixed video camera to measure debris-flow surface velocity, Proceedings of the Second International Conference on Debris-flow Hazards Mitigation: Mechanics, Prediction, and Assessment, Taipei, 16-18 August, 2000, edited by: Wieczorek, G., Naeser, N., and Balkema, A. A., Rotterdam, 273-281, 2000.

Arattano, M. and Marchi, L.: Video-derived velocity distribution along a debris flow surge, Phys. Chem. Earth Pt. B, 25, 781-784, 2000.

Arattano, M., Marchi, L., and Cavalli, M.: Analysis of debrisflow recordings in an instrumented basin: confirmations and new findings, Nat. Hazards Earth Syst. Sci., 12, 679-686, https://doi.org/10.5194/nhess-12-679-2012, 2012.

Berti, M. R., Genevois, R., LaHusen, R. G., Simoni, A., and Tecca, P. R.: Debris flow monitoring in the Acquabona watershed in the Dolomites (Italian Alps), Phys. Chem. Earth Pt. B, 25, 707-715, 2000.

Cavalli, M. and Marchi, L.: Characterisation of the surface morphology of an alpine alluvial fan using airborne LiDAR, Nat. Hazards Earth Syst. Sci., 8, 323-333, https://doi.org/10.5194/nhess8-323-2008, 2008.

Cavalli, M., Trevisani, S., Comiti, F., and Marchi, L.: Geomorphometric assessment of spatial sediment connectivity in small Alpine catchments, Geomorphology, 188, 31-41, https://doi.org/10.1016/j.geomorph.2012.05.007, 2013.

Cavalli, M., Goldin, B., Comiti, F., Brardinoni, F., and Marchi, L.: Assessment of erosion and deposition in steep mountain basins by differencing sequential digital terrain models, Geomorphology, 291, 4-16, https://doi.org/10.1016/j.geomorph.2016.04.009, 2017.

Chen, C. L.: Comprehensive review of debris flow modeling concepts in Japan, in: Reviews in engineering geology, edited by: Costa, J. E. and Wieczorek, G. F., VII, Debris flows/ avalanches: process, recognition, and mitigation, Boulder, CO, 13-29, 1987.
Coe, J. A., Kinner, D. A., and Godt, J. W.: Initiation conditions for debris flows generated by runoff at Chalk Cliffs, central Colorado, Geomorohology, 96, 270-297, 2008.

Comiti, F., Marchi, L., Macconi, P., Arattano, M., Bertoldi, G., Borga, M., Brardinoni, F., Cavalli, M., D’Agostino, V., Penna, D., and Theule, J.: A new monitoring station for debris flows in the European Alps: first observations in the Gadria basin, Nat. Hazards, 73, 1175-1198, https://doi.org/10.1007/s11069014-1088-5, 2014.

Costa, J. E.: Physical geomorphology of debris flows, in: Developments and Applications in Geomorphology, edited by: Costa, J. E. and Fleisher, P. J., Springer Verlag, 268-317, 1984.

D'Agostino, V. and Bertoldi, G.: On the assessment of the management priority of sediment source areas in a debrisflow catchment, Earth Surf. Proc. Land., 39, 656-668, https://doi.org/10.1002/esp.3518, 2014.

Ferguson, R. I.: River channel slope, flow resistance, and gravel entrainment thresholds, Water Resour. Res., 48, W05517, https://doi.org/10.1029/2011WR010850, 2012.

Fujita, I., M. Muste, and A. Kruger: Large-scale particle image velocimetry for flow analysis in hydraulic engineering applications, J. Hydraul. Res., 36, 397-414, 1998.

Genevois, A., Galgaro, R., and Tecca, P. R.: Image analysis for debris flow properties estimation, Phys. Chem. Earth Pt. C, 26, 623-631, 2001.

Hauet A., Creutin J.-D., and Belleudy P.: Sensitivity study of largescale particle image velocimetry measurement of river discharge using numerical simulation, J. Hydrol., 349, 178-190, 2008.

Hungr, O., Morgan, G. C., and Kellerhals, R.: Quantitative analysis of debris torrent hazards for design of remedial measures, Can. Geotech. J., 21, 663-677, 1984.

Hungr, O., Evans, S. G., Bovis, M., and Hutchinson, J. N.: Review of classification of landslides of flow type, Environ. Eng. Geosci., 7, 221-238, 2001.

Hürlimann, M., Rickenmann, D., and Graf, C.: Field and monitoring data of debris-flow events in the Swiss Alps, Can. Geotech. J., 40, 161-175, 2003.

Iverson, R. M.: The physics of debris flows, Rev. Geophys., 35, 245-296, 1997.

Jacquemart, M., Meier, L., Graf, C., and Morsdorf, M.: 3D dynamics of debris flows quantified at sub-second intervals from laser profiles, Nat. Hazards, 89, 785-800, doi.org/10.1007/s11069017-2993-1, 2017.

Javernick, L., Brasington, J., and Caruso, B.: Modelling the topography of shallow braided rivers using structure-from-motion photogrammetry, Geomorphology, 213, 166-182, 2014.

Koch, T.: Testing various constitutive equations for debris flow modelling, in: Hydrology, Water Resources and Ecology in Headwaters, edited by: Kovar, K., IAHS, Publ. No. 248, Merano, Italy, 249-257, 1998.

Le Boursicaud, R., Pénard, L., Hauet, A., Thollet, F., and Le Coz, J.: Gauging extreme floods on YouTube: application of LSPIV to home movies for the post-event determination of stream discharges, Hydrol. Process. 30, 90-105, 2016.

Le Coz, J., Hauet, A., Pierrefeu, G., Dramais, G., and Camenen, B.: Performance of image-based velocimetry (LSPIV) applied to flashflood discharge measurements in Mediterranean rivers, J. Hydrol., 394, 42-52, 2010. 
Le Coz, J., Jodeau, M., Hauet, A., Marchand, B., and Le Boursicaud, R.: Image-based velocity and discharge measurements in field and laboratory river engineering studies using the free Fudaa-LSPIV software, Proceedings of the International Conference on Fluvial Hydraulics, RIVER FLOW, 2014, 1961-1967, 2014.

Marchi, L., Arattano, M., and Deganutti, A. M.: Ten years of debrisflow monitoring in the Moscardo Torrent (Italian Alps), Geomorphology, 46, 1-17, 2002.

McCoy, S. W., Kean, J. W., Coe, J. A., Staley, D. M., Wasklewicz, T. A., and Tucker, G. E.: Evolution of a natural debris flow: in situ measurements of flow dynamics, video imagery, and terrestrial laser scanning, Geology, 38, 735-738, 2010.

Muste, M., Hauet, A., Fujita, I., Legout, C., and Ho, H.-C.: Capabilities of large-scale particle image velocimetry to characterize shallow free-surface flows, Adv. Water Resour., 70, 160-171, https://doi.org/10.1016/j.advwatres.2014.04.004, 2014.

Navratil, O., Liébault, F., Bellot, H., Travaglini, E., Theule, J., Chambon, G., and Laigle, D.: High-frequency monitoring of debris-flow propagation along the Réal Torrent, Southern French Prealps, Geomorphology, 201, 157-171, 2013.

Phillips, C. J. and Davies, T. R. H.: Determining rheological parameters of debris flow material, Geomorphology, 4, 101-110, 1991.

Piermattei, L., Carturan, L., and Guarnieri, A.: Use of terrestrial photogrammetry based on structure-from-motion for mass balance estimation of a small glacier in the Italian alps, Earth Surf. Proc. Land., 40, 1791-1802, https://doi.org/10.1002/esp.3756, 2015.

Pierson, T. C.: Flow behavior of channelized debris flows, Mt. St. Helens, Washington, Hillslope Processes, Allen \& Unwin, Boston, 1986.

Pierson, T. C. and Scott, K. M.: Downstream Dilution of a Lahar: Transition from Debris Flow to Hyperconcentrated Streamflow, Water Resour. Res., 21, 1511-1524, 1985.
Prochaska, A. B., Santi, P. M., Higgins, J. D., and Cannon, S. H.: A study of methods to estimate debris flow velocity, Landslides, 431-444, https://doi.org/10.1007/s10346-008-0137-0, 2008.

Rickenmann, D.: Empirical relationships for debris flows, Nat. Hazards, 19, 47-77, 1999.

Rickenmann, D. and Recking, A.: Evaluation of flow resistance in gravel-bed rivers through a large field data set, Water Resour. Res., 47, W07538, https://doi.org/10.1029/2010wr009793, 2011.

Rickenmann, D., Weber, D., and Stepanov, B.: Erosion by debris flows in field and laboratory experiments, in: Debris-Flow Hazards Mitigation: Mechanics, Prediction, and Assessment, edited by: Rickenmann, D. and Chen, C. L., Millpress, Rotterdam, The Netherlands, 883-894, 2003.

Scheidl, C., McArdell, B. W., and Rickenmann, D.: Debris-flow velocities and superelevation in a curved laboratory channel, Can. Geotech. J., 52, 305-317, https://doi.org/10.1139/cgj-20140081, 2014.

Stumpf, A., Augereau E., Delacourt C., and Bonnier J.: Photogrammetric discharge monitoring of small tropical mountain rivers: A case study at Rivière des Pluies, Réunion Island, Water Resour. Res., 52, 4550-4570, https://doi.org/10.1002/2015WR018292, 2016.

Suwa, H., Okunishi, K., and Sakai, M.: Motion, debris size and scale of debris flows in a valley on Mount Yakedake, Japan, IAHS Publ. No. 217, 239-248, 1993.

Westoby, M. J., Brasington, J., Glasser, N. F., Hambrey, M. J., and Reynolds, J. M.: "Structure-from-Motion" photogrammetry: A low-cost, effective tool for geoscience applications, Geomorphology, 179, 300-314, https://doi.org/10.1016/j.geomorph.2012.08.021, 2012. 